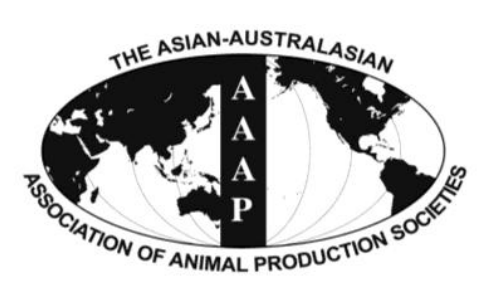

\title{
Effect of Curing Time on the Physicochemical and Sensory Properties of Beef Jerky Replaced Salt with Soy Sauce, Red Pepper Paste and Soybean Paste
}

\author{
H. J. Lim, G. D. Kim ${ }^{1}$, E. Y. Jung, H. W. Seo, S. T. Joo, S. K. Jin², and H. S. Yang* \\ Division of Applied Life Science Graduate School (BK21 plus). Institute of Agriculture and Life Science, \\ Gyeongsang National University, Jinju, 660-701, Korea
}

\begin{abstract}
This study was done to investigate the quality properties of beef jerky with soy sauce, red pepper paste, and soybean paste replacing salt. Sliced beef samples were cured in salt (control), soy sauce, red pepper paste, and soybean paste for 24 or $48 \mathrm{~h}$ and then dried at $70^{\circ} \mathrm{C}$ for $8 \mathrm{~h}$. Treatments showed higher final moisture content and lower $\mathrm{Na}^{+}$concentration than the control after drying for $8 \mathrm{~h}$. The lightness and shear force values were lower in all treatment samples than in the control during $48 \mathrm{~h}$ of curing time. In particular, lower lipid oxidation was found in the jerky cured with red pepper paste than in the control. Sensory evaluation showed that color, flavor, and tenderness of jerky samples were improved by replacing salt with soy sauce, red pepper paste and soybean paste, and higher likeability scores of the beef jerky were obtained among those treatments after $48 \mathrm{~h}$ of curing time. (Key Words: Beef Jerky, Replaced Salt, Soy Sauce, Red Pepper Paste, Soybean Paste)
\end{abstract}

\section{INTRODUCTION}

Jerky is one of the oldest meat products that is preserved by salting and drying. It is relatively simple to process, has a typical flavor, and needs no refrigeration during commercial distribution due to its low water activity $\left(a_{w}\right)$ (Yang et al., 2009a). To achieve stability, jerky is dried to $\mathrm{a}_{\mathrm{w}} 0.70$ to 0.85 (Quintion et al., 1997). Hurdles to microbial survival and growth include drying temperature, low $\mathrm{a}_{\mathrm{w}}$, and preservatives such as salt and organic acids depending on the composition of the marinate mixture (Gailani et al., 1986; Quintion et al., 1997).

Salt is the most commonly used functional ingredient in processed meat product, and is used primarily for flavor but

\footnotetext{
* Corresponding Author: H. S. Yang. Tel: +82-55-772-1948, Fax: +82-55-772-1949, E-mail: hsyang@ gnu.ac.kr

${ }^{1}$ Department of Food Science and Biotechnology, Kyungnam University, Changwon 631-701, Korea.

2 Department of Animal Resources Technology, Gyeongnam National University of Science and Technology, Jinju 660-758, Korea.

Submitted Dec. 27, 2013; Revised Mar. 4, 2014; Accepted Apr. 8, 2014
}

also has secondary functions including inhibiting microbial growth, extending shelf-life and increasing protein hydration (Han et al., 2011). It increases protein hydration by increasing the ionic strength in meat products, and increased protein hydration leads to increased water binding in intact muscle pieces and increased soluble protein concentrations in meat products (Chinachoti and Schmidt 1991).

However, the meat industry has explored various options to lower sodium in processed meats (Lim et al., 2013). In recent years, an increased effort has been made to reduce the amount of salt in foodstuffs (Costa-Corredor et al., 2009). There is a trend to reduce the salt content in foods because excessive sodium intake contributes to high blood pressure in salt susceptible consumers (Hee and Mac Gregor, 2010). There is considerable evidence that food consumption is strongly related to health, and that high levels of sodium intake may be crucial for the development of hypertension and the age related rise of blood pressure typically observed in modern society (McCarty, 2004).

To improve the sensory qualities of jerky, we introduced the East Asia, including Korea, traditional sauce such as soy

Copyright $@ 2014$ by Asian-Australasian Journal of Animal Sciences This is an open-access article distributed under the terms of the Creative Commons Attribution Non-Commercial License (http://creativecommons.org/licenses/by-nc/3.0/), which permits unrestricted non-commercial use, distribution, and reproduction in any medium, provided the original work is properly cited. 
sauce, red pepper paste, and soybean paste as the marinade. The East Asia traditional sauces are produced from soybean with $5 \%$ to $20 \%$ of salt for several months at the ambient temperature. Soybean and soy foods have been used as beneficial dietary and nutritive materials in several Asian countries due to their high quality proteins $(\sim 40 \%)$ and many other functional substances like phenolic acids and isoflavones (Zhang et al., 2003). Also, soybean or soy foods may be effective in reducing the risk of heart diseases and various cancers. Furthermore, an intake of soy proteins or soy isoflavones decreased to the diastolic blood pressure, serum total cholesterol, or low density lipoprotein (LDL)cholesterol in the subject groups with high or normal cholesterol level (Anderson et al., 1995).

One of the most important attributes of jerky is the curing time that can be measured as quality properties. It has been demonstrated that processing time affects aroma and flavor traits (Flores et al., 1997). The curing time is also correlated to lipolysis (Andres et al., 2005), which is one of the main degradation mechanisms affecting lipids during meat processing (Larrea et al., 2007).

Therefore, the objective of this study is to investigate the effect of different curing time on the physicochemical and sensory properties of beef jerky with salt replaced by soy sauce, red pepper paste and soybean paste, and to determine if curing agents can be effectively utilized for beef jerky processing.

\section{MATERIALS AND METHODS}

\section{Preparation of beef jerky samples}

A total of five cattle (Hanwoo, Korean native cattle, market weight 425 to $455 \mathrm{~kg}$ ) were randomly selected at a slaughter plant. The muscle of beef semimembranosus (BS) was dissected from each carcass $48 \mathrm{~h}$ postmortem. All subcutaneous and intermuscular fat and visible connective tissue were removed from the fresh muscles. The sample was sliced to $0.5 \mathrm{~cm}$ thick pieces with a meat slicer (HFS 350G, Hankook Fujee Industries Co. Ltd, Hwaseong, Korea) and cut into cubes of $15.0 \times 4.0 \times 0.5 \mathrm{~cm}$. Sliced BS muscles were cut parallel in the same direction as muscle fibers. Commercial salt, soy sauce, red pepper paste and soybean paste were purchased from a local food additives plant. Salt, soy sauce, red pepper paste and soybean paste solution were diluted with water to the same salinity (15\%) content. The salt-water was prepared by dissolving sodium chloride in distilled water and its salinity adjusted to $15 \%$ salt as the same salinity of soy sauce, red pepper paste and soybean paste. The red pepper paste and soybean paste solutions were homogenized with a Polytron homogenizer (T25-B, IKA Sdn. Bhd., Rawang, Malaysia) at 8,000 rpm for $30 \mathrm{~s}$. The slurry was filtered through two layers of cheese cloth to remove the particles. The sliced samples were then cured for $24 \mathrm{~h}$ or $48 \mathrm{~h}$, in a cure solution containing $10 \%$ water, $2 \%$ salt solution (soy sauce, red pepper paste, and soybean paste), $6 \%$ sugar, $0.2 \%$ pepper, and $0.028 \%$ sodium nitrate (based on raw meat weight; $\mathrm{v} / \mathrm{w})$.

After curing, all samples were dried using a dryer (DS80-1, Dasol Scientific Co. Ltd, Hwaseong, Korea) at a temperature of $70^{\circ} \mathrm{C}$. There was adequate air distribution between samples receiving the same drying treatment. Water activity measurements (AQS-2, Nagy mess system, Gäufelden, Germany) were then taken, to the target $\mathrm{a}_{\mathrm{w}}<0.80$. Jerky samples were recorded at $1 \mathrm{~h}$ intervals throughout drying. The ultimate $a_{w}$ of control and treatments samples after $8 \mathrm{~h}$ of drying was 0.75 to 0.77 . Dried products, in general, have been considered as one of the safest food groups for humans since they involve hurdles to microbial survival and growth. After drying and cooling to ambient $\left(25^{\circ} \mathrm{C}\right)$ temperature the jerky samples were loosely packed, without vacuum, plastic bags (single package). The moisture content, $\mathrm{pH}$, lightness, shear force, salinity, $\mathrm{Na}^{+}$ concentration, thiobarbituric acid reactive substance (TBARS) and sensory evaluation were measured at 24 and $48 \mathrm{~h}$ of curing time. A flow diagram depicting beef jerky preparation is shown in Figure 1.

\section{Moisture content}

Moisture content was determined according to AOAC (2000). The strips were dried in an air oven at $102^{\circ} \mathrm{C}$ for 24 $\mathrm{h}$ and the total moisture content of individual beef strips was determined from their pre-dry and dry weights expressed as the percentage of pre-dry weight and gram water per gram of dry weight.

pH

The $\mathrm{pH}$ was measured in triplicate using a digital $\mathrm{pH}$

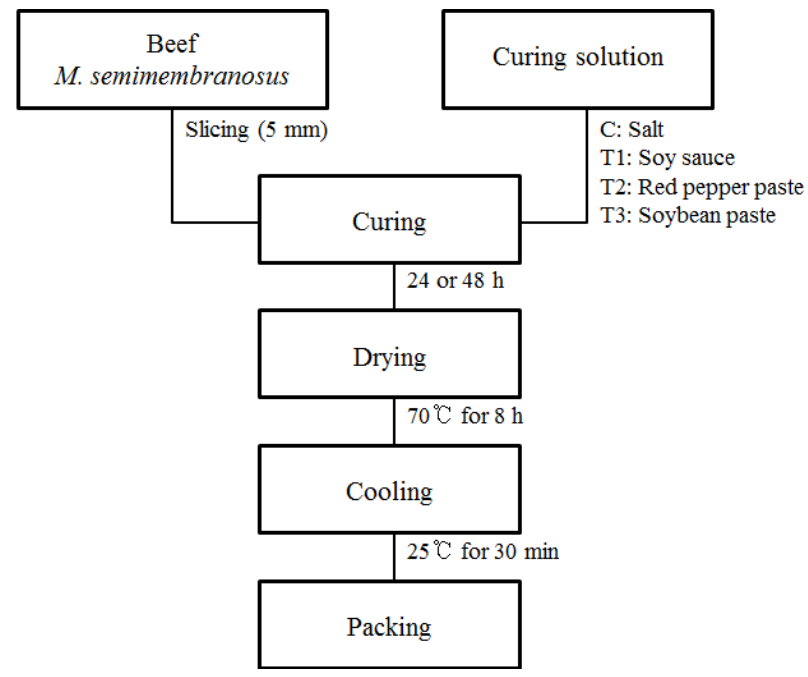

Figure 1. The diagram of beef jerky manufacturing. 
meter (MP230, Mettler-Toledo, Greifensee, Switzerland). Approximately $3 \mathrm{~g}$ of the jerky sample was cut into small pieces and $27 \mathrm{~mL}$ of distilled water was added. Slurry was then made using a homogenizer (T25basic, IKA, Rawang, Malaysia) and $\mathrm{pH}$ was recorded. The $\mathrm{pH}$ meter was calibrated daily with standard buffers of $\mathrm{pH} 4.0$ and 7.0 at $25^{\circ} \mathrm{C}$.

\section{Instrument color}

The surface lightness color value of the jerky samples were measured by the Commission internationale de I'éclairage (CIE) L* system using a Minolta Chroma meter CR-200 (Minolta Camera Co., Osaka, Japan), whereby measurements are standardized with respect to a white calibration plate $(\mathrm{Y}=93.5, \mathrm{x}=0.3132, \mathrm{y}=0.3198)$.

\section{Shear force}

Shear force $\left(\mathrm{N} / \mathrm{cm}^{2}\right)$ was measured using the Instron Universal Testing Machine (Model 3343, Instron, Norwood, MA, USA) with a V-shaped shear blade. From six samples, $0.5 \times 4.0 \mathrm{~cm}$ cross sections (across to the fibers) were cut for cutting force measurements. The beef jerky samples were placed at right angles to the blade. The crosshead speed was $100 \mathrm{~mm} / \mathrm{min}$ and the full scale load was $49 \mathrm{~N}$.

\section{Salinity}

The salinity was measured a digital salinity meter (Takemura, TM-30D, Tokyo, Japan). Approximately $3 \mathrm{~g}$ of the jerky sample was cut into small pieces and $27 \mathrm{~mL}$ of distilled water was added. Slurry was then made using a homogenizer (T25basic, IKA, Malaysia) and salinity was recorded.

\section{$\mathrm{Na}^{+}$concentration}

About $1.0 \mathrm{~g}$ dried beef jerky was put into burning cup and added pure $20 \mathrm{~mL} \mathrm{HNO}_{3}$. The sample was incinerated in microwave oven at $200^{\circ} \mathrm{C}$ temperature. Before each element read in equipment, standards at different concentrations for each element were read in inductively coupled plasma atomic emission spectrometer (ICP-AES). Then, quantitative concentrations were determined with an ICP-AES.

\section{2-Thiobarbituric acid reactive substance (TBARS)}

The 2-TBARS content of beef jerky samples from each treatment was determined using the thiobarbituric acid (TBA) distillation procedure by Yang et al. (2009a) as modified from a procedure by Sinnhuber and Yu (1977). A $0.4 \mathrm{~g}$ sample of beef jerky was weighed into a $30 \mathrm{~mL}$ screw capped pyrex tube (PYREX, Tewksbury, MA, USA). Two to 3 drops of antioxidant solution (A: $0.3 \mathrm{~g}$ butylated hydroxyl anisole $+5.4 \mathrm{~g}$ propylene glycol, B: $0.3 \mathrm{~g}$ butylated hydroxyl toluene+4.0 g tween 20), $3 \mathrm{~mL}$ TBA solution, and $17 \mathrm{~mL}$ TCA-HCl solution (trichloroacetic acid+0.6 N HCl) were added. The mixture was vortexed and then incubated in a $100^{\circ} \mathrm{C}$ boiling water bath for $30 \mathrm{~min}$ to develop color. The sample was cooled in cold water for $10 \mathrm{~min}$. A $5 \mathrm{~mL}$ supernatant solution was transferred to the $10 \mathrm{~mL}$ glass tube, $2 \mathrm{~mL}$ of chloroform was added and centrifuged for $15 \mathrm{~min}$ at $2,000 \times \mathrm{g}$. The absorbance of the resulting supernatant solution was determined at $532 \mathrm{~nm}$ against a blank sample containing all the reagents minus the sample.

TBARS (mg malonaldehyde/kg sample)

$=[($ absorbance sample - absorbance blank $) \times 46]$

$/[$ sample weight $(\mathrm{g}) \times 5]$

\section{Sensory evaluation}

Beef jerky samples from each treatment were evaluated by an 8-member trained expert descriptive attribute sensory panel in the Gyeongsang National University. The panelist were selected and trained according to the procedures of Meilgaard et al. (1999). Panelists were given samples representing anchor points for each attribute, and training sessions using dried beef with/without soy sauce, red pepper paste, and soybean paste in the meat lab. The panelists were trained using a 9-point scale ("9 extremely intense" and "1 slightly intense") for color, dried beef flavor, soy sauce/red pepper paste/soybean paste flavor and texture attributes. Final anchor point ratings were decided upon by training panel after initial evaluation and discussion.

For the samples, panelists evaluated the samples for appearance, color, off-flavor, juiciness, tenderness, and overall acceptability using a 9-point hedonic scale as described by Meilgaard et al. (1999), where 1 meant "extremely dislike" and 9 meant "extremely like".

\section{Statistical analysis}

Data from three replications were analyzed by analysis of variance (ANOVA) using statistical analysis systems (SAS, 2000). The ANOVA was adopted for designing the mathematical model using SAS 9.2 (SAS Institute, Inc., USA). Duncan's multiple range tests were used to determine the statistical significance among the means at a significance level of $95 \%$.

\section{RESULTS AND DISCUSSION}

\section{Moisture content, $\mathrm{pH}$, lightness and shear force}

The results of moisture content, $\mathrm{pH}$, lightness and shear force are presented in Table 1. In this study, the moisture content of beef jerky samples ranged from $27.92 \%$ to $20.61 \%$. The final moisture content of beef jerky increased with increasing curing time $(\mathrm{p}<0.05)$. The final moisture 
Table 1. Effect of curing time on the moisture content, $\mathrm{pH}, \mathrm{CIE}$ $\mathrm{L}^{*}$ and shear force of beef jerky

\begin{tabular}{|c|c|c|c|}
\hline \multirow{2}{*}{ Treatment } & \multirow{2}{*}{$\begin{array}{l}\text { Curing } \\
\text { solution }^{1}\end{array}$} & \multicolumn{2}{|c|}{ Curing time (h) } \\
\hline & & 24 & 48 \\
\hline \multirow{4}{*}{$\begin{array}{l}\text { Moisture content } \\
(\%)\end{array}$} & $\mathrm{C}$ & $20.61 \pm 0.38^{\mathrm{Bc}}$ & $24.84 \pm 0.23^{\mathrm{Ac}}$ \\
\hline & $\mathrm{T} 1$ & $22.17 \pm 0.16^{\mathrm{Bb}}$ & $27.92 \pm 0.02^{\mathrm{Aa}}$ \\
\hline & $\mathrm{T} 2$ & $23.57 \pm 0.48^{\mathrm{a}}$ & $25.51 \pm 0.72^{c}$ \\
\hline & $\mathrm{T} 3$ & $22.91 \pm 0.34^{\mathrm{Bab}}$ & $27.01 \pm 0.76^{\mathrm{Ab}}$ \\
\hline \multirow[t]{4}{*}{$\mathrm{pH}$} & $\mathrm{C}$ & $5.90 \pm 0.03^{\mathrm{Aa}}$ & $5.76 \pm 0.01^{\mathrm{Bb}}$ \\
\hline & $\mathrm{T} 1$ & $5.81 \pm 0.00^{\mathrm{Bb}}$ & $5.86 \pm 0.00^{\mathrm{Aa}}$ \\
\hline & $\mathrm{T} 2$ & $5.68 \pm 0.01^{\mathrm{c}}$ & $5.68 \pm 0.02^{\mathrm{c}}$ \\
\hline & $\mathrm{T} 3$ & $5.68 \pm 0.00^{c}$ & $5.69 \pm 0.01^{\mathrm{c}}$ \\
\hline \multirow{4}{*}{$\begin{array}{l}\text { CIE L* } \\
\text { (Lightness) }\end{array}$} & $\mathrm{C}$ & $30.45 \pm 0.31^{\mathrm{Aa}}$ & $27.19 \pm 0.07^{\mathrm{Ba}}$ \\
\hline & $\mathrm{T} 1$ & $27.16 \pm 0.21^{\mathrm{Ab}}$ & $26.04 \pm 0.38^{\mathrm{Bb}}$ \\
\hline & $\mathrm{T} 2$ & $24.71 \pm 0.30^{\mathrm{Bd}}$ & $25.66 \pm 0.35^{\mathrm{Ab}}$ \\
\hline & $\mathrm{T} 3$ & $25.54 \pm 0.32^{\mathrm{Ac}}$ & $24.84 \pm 0.17^{\mathrm{Bc}}$ \\
\hline \multirow{4}{*}{$\begin{array}{l}\text { Shear force } \\
\left(\mathrm{N} / \mathrm{cm}^{2}\right)\end{array}$} & $\mathrm{C}$ & $91.53 \pm 2.25^{\mathrm{a}}$ & $92.02 \pm 3.23^{\mathrm{a}}$ \\
\hline & $\mathrm{T} 1$ & $80.36 \pm 0.78^{b}$ & $75.26 \pm 7.54^{\mathrm{b}}$ \\
\hline & $\mathrm{T} 2$ & $84.28 \pm 1.67^{\mathrm{Ab}}$ & $75.07 \pm 0.39^{\mathrm{Bb}}$ \\
\hline & $\mathrm{T} 3$ & $82.71 \pm 6.96^{\mathrm{b}}$ & $72.62 \pm 5.19^{\mathrm{b}}$ \\
\hline
\end{tabular}

CIE, Commission internationale de I'éclairage.

${ }^{1} \mathrm{C}$, control, salt cured; T1, replacement of salt with soy sauce; T2, replacement of salt with red pepper paste; T3, replacement of salt with soybean paste.

A-B Different capital letter indicate significant differences within curing time $(\mathrm{p}<0.05)$.

${ }^{a-d}$ Different small letters indicate significant differences within curing solution $(\mathrm{p}<0.05)$.

content was higher in all treatments than in the control sample at $24 \mathrm{~h}$ of curing time. At $48 \mathrm{~h}$ of curing time, soy sauce (T1) and soybean paste (T3) had higher moisture content than the control. Moisture content has a decisive effect on the stability of intermediate-moisture (IM) foods (Labuza et al., 1970). In general, commercial IM foods have moisture contents of $20 \%$ to $40 \%$ (Jose et al., 1994). When manufacturing IM food, it is important to control the water content because $a_{w}$ is closely related to $a_{w}$ (Leistner, 1987). This relationship between moisture content and $a_{w}$ may be very effective for controlling the quality and sensory properties of the jerky. This is one of the benefits of controlling the textural properties of beef jerky. Specific changes in flavor, texture, and stability of processed meat products have been associated with relatively narrow $\mathrm{a}_{\mathrm{w}}$ ranges (Chang et al., 1991).

The $\mathrm{pH}$ values varied from 5.90 to 5.68 . The $\mathrm{pH}$ value of all treatments was significantly lower than that of the control sample at $24 \mathrm{~h}$ of curing time $(\mathrm{p}<0.05)$. Particularly, $\mathrm{T} 2$ and $\mathrm{T} 3$ had lower $\mathrm{pH}$ vales than those of other jerky samples until $48 \mathrm{~h}$ of curing time $(\mathrm{p}<0.05)$. Joes et al., (1994) reported that the average $\mathrm{pH}$ for IM meat products was in the broad range of 4.72 to 6.73. Leistner (1987) reported that low $\mathrm{pH}$ can inhibit or delay the spoilage of various dried meat products by mold and microorganism growth. Also, the $\mathrm{pH}$ values of soy sauce, red pepper paste and soybean paste solutions were $6.72 \pm 0.02,5.03 \pm 0.01$, and $5.24 \pm 0.01$ (not presented). Therefore, this shows that the $\mathrm{pH}$ value of beef jerky can be affected by curing ingredient.

The lightness value increased during curing $48 \mathrm{~h}$ in the T2 sample. However, the lightness values of control, T1 and T3 jerky samples decreased with increasing curing time $(p<0.05)$. In comparison to the control, the lightness value was significantly lower in all treatments than the control sample during $48 \mathrm{~h}$ of curing time $(\mathrm{p}<0.05)$. Color is a major factor in consumer purchase decisions because it is presumed to be indicator of meat quality (Brewer et al., 2002). The surface color values of beef jerky can change according to the marinade ingredients at the same temperature, and the CIE L-value decreases with soy sauce, red pepper paste, and soybean paste solutions (Lim et al., 2013). Consequently, in the present experiment the replacement of salt with soy sauce, red pepper paste, and soybean paste solutions changed the color attributes of the beef jerky by decreasing lightness.

Texture is also an important factor in the preparation of meat products and in consumer preference (Guerrero et al., 1999). One of the most important attributes of jerky is also the hardness, which can be measured as shear force. The shear force values can be used to characterize the IM products, and is defined as the maximum force attained as a blade shears through beef jerky samples. The shear force values of the samples varied from 92.02 to $72.62\left(\mathrm{~N} / \mathrm{cm}^{2}\right)$. In comparison to the control, the shear force value was significantly lower in all treatments than in the control sample until $48 \mathrm{~h}$ of curing time $(\mathrm{p}<0.05)$. The low shear force levels in soy sauce, red pepper paste, and soybean paste replacement cured samples seem to be due to high moisture content. These results agree with a previous report on the shear force or hardness being affected by moisture content (Yang et al., 2009b).

\section{Salinity and $\mathrm{Na}^{+}$concentration}

The results of salinity and $\mathrm{Na}^{+}$concentration are presented in Table 2. Salt is a commonly used functional ingredient in processed meat products, but the meat industry has explored various options to lower sodium in processed meats (Lim et al., 2013). Salinity values of all beef jerky samples showed a decreasing trend with increased curing time. Particularly, the salinity value of the control and T3 beef jerky samples decreased with increasing curing time $(\mathrm{p}<0.05)$. The salinity of all treatments was significantly lower than that of the control at $24 \mathrm{~h}$ of curing time $(\mathrm{p}<0.05)$.

The $\mathrm{Na}^{+}$concentration of beef jerky samples varied from 0.95 to 0.25 with curing time, and all beef jerky samples did not show significant changes in $\mathrm{Na}^{+}$ 
Table 2. Effect of curing time on the salinity, $\mathrm{Na}^{+}$concentration and TBARS of beef jerky

\begin{tabular}{lccc}
\hline \multirow{2}{*}{ Treatment } & Curing & \multicolumn{2}{c}{ Curing time (h) } \\
\cline { 3 - 4 } solution & \multicolumn{1}{c}{24} & \multicolumn{1}{c}{48} \\
\hline Salinity (\%) & $\mathrm{C}$ & $3.05 \pm 0.07^{\mathrm{Aa}}$ & $2.55 \pm 0.07^{\mathrm{B}}$ \\
& $\mathrm{T} 1$ & $2.90 \pm 0.00^{\mathrm{b}}$ & $2.85 \pm 0.07$ \\
& $\mathrm{~T} 2$ & $2.65 \pm 0.07^{\mathrm{c}}$ & $2.60 \pm 0.14$ \\
& $\mathrm{~T} 3$ & $2.80 \pm 0.00^{\mathrm{Ab}}$ & $2.55 \pm 0.07^{\mathrm{B}}$ \\
$\mathrm{Na}^{+}(\%)$ & $\mathrm{C}$ & $0.85 \pm 0.07^{\mathrm{a}}$ & $0.95 \pm 0.07^{\mathrm{a}}$ \\
& $\mathrm{T} 1$ & $0.85 \pm 0.07^{\mathrm{a}}$ & $0.90 \pm 0.14^{\mathrm{a}}$ \\
& $\mathrm{T} 2$ & $0.35 \pm 0.07^{\mathrm{b}}$ & $0.25 \pm 0.07^{\mathrm{c}}$ \\
TBARS & $\mathrm{T} 3$ & $0.75 \pm 0.07^{\mathrm{a}}$ & $0.60 \pm 0.00^{\mathrm{b}}$ \\
(mg malonaldehyde & $\mathrm{C}$ & $2.94 \pm 0.11^{\mathrm{b}}$ & $3.08 \pm 0.22^{\mathrm{a}}$ \\
& $\mathrm{T} 1$ & $3.85 \pm 0.07^{\mathrm{Aa}}$ & $3.13 \pm 0.44^{\mathrm{Ba}}$ \\
& $\mathrm{T} 2$ & $1.59 \pm 0.20^{\mathrm{Bd}}$ & $2.27 \pm 0.03^{\mathrm{Ab}}$ \\
& $\mathrm{T} 3$ & $2.46 \pm 0.02^{\mathrm{Bc}}$ & $3.13 \pm 0.13^{\mathrm{Aa}}$ \\
\hline
\end{tabular}

TBARS, thiobarbituric acid reactive substance.

${ }^{1} \mathrm{C}$, control, salt cured; $\mathrm{T} 1$, replacement of salt with soy sauce; $\mathrm{T} 2$, replacement of salt with red pepper paste; T3, replacement of salt with soybean paste.

${ }^{\text {A-B }}$ Different capital letter indicate significant differences within curing time $(\mathrm{p}<0.05)$

${ }^{a-d}$ Different small letters indicate significant differences within curing solution $(\mathrm{p}<0.05)$

concentration during $48 \mathrm{~h}$ of curing time. The T2 jerky sample showed lower $\mathrm{Na}^{+}$concentration than those of other samples at $24 \mathrm{~h}$ of curing time, and the T2 and T3 jerky samples showed lower $\mathrm{Na}^{+}$concentrations than those of other jerky samples at $48 \mathrm{~h}$ of curing time. Therefore, it is suggested that replacing salt with red pepper paste and soybean paste could be used to reduce the $\mathrm{Na}^{+}$ concentration of the meat products, providing consumers with healthy food.

\section{2-Thiobarbituric acid reactive substance (TBARS)}

The TBARS value is the most common indicator used to measure the degree of lipid oxidation in meat products (Obanu, 1988). Lipid oxidation is a major cause of deterioration in the flavor, odor, taste, color, texture, and appearance of meat and meat products (Aalhus and Dugan, 2004). The results of TBARS value are presented in Table 2. In this study, the T2 and T3 jerky samples showed lower TBARS values than the control sample for $24 \mathrm{~h}$ of curing time $(p<0.05)$. The TBARS value of beef jerky containing red pepper paste was significantly lower than those for the other treatments for $48 \mathrm{~h}$ of curing time $(\mathrm{p}<0.05)$. Also, the TBARS value of the T2 and T3 beef jerky samples increased with increasing curing time $(p<0.05)$. It is normally accepted that the TBARS value increases in meat with increasing storage time. Particularly, TBARS values became higher as drying time increased (Chen et al., 2002) and were dependent on the salt concentration (Sárraga and Garćia-Regueiro, 1998). We found that there was a significant effect of the $\mathrm{Na}^{+}$concentration on lipid oxidation.
It seems that the different curing ingredients may help to form malonaldehyde throughout the curing. Also, soy sauce contains several antioxidants such as melanoidins (formed during fermentation), phenolic compounds and free amino acids. Gochujang (Korean red pepper paste) possesses various biological activities, including anti-obesity (Ahn et al., 2006), anti-mutagenic (Choo, 2000), and anti-cancer effects (Kim et al., 2005). Soybean paste contains large amounts of isoflavone aglucons and phenolic acids (Chung et al., 2011).

\section{Sensory evaluation}

Sensory panels were convened to assess the effects on the color, flavor, off-flavor, juiciness, tenderness and overall acceptability of beef jerky samples (Table 3). The most important sensory attributes of jerky (and other snack foods) are texture, color and flavor, which are determined by the raw material and numerous technological factors

Table 3. Effect of curing time on the sensory evaluation of beef jerky

\begin{tabular}{|c|c|c|c|}
\hline \multirow{2}{*}{ Treatment } & \multirow{2}{*}{$\begin{array}{l}\text { Curing } \\
\text { solution }^{1}\end{array}$} & \multicolumn{2}{|c|}{ Curing time $(\mathrm{h})$} \\
\hline & & 24 & 48 \\
\hline \multirow[t]{4}{*}{ Color } & $\mathrm{C}$ & $4.04 \pm 0.44^{\mathrm{Bb}}$ & $5.33 \pm 0.24^{\mathrm{A}}$ \\
\hline & $\mathrm{T} 1$ & $4.93 \pm 0.29^{\mathrm{Ba}}$ & $5.70 \pm 0.55^{\mathrm{A}}$ \\
\hline & $\mathrm{T} 2$ & $5.25 \pm 0.30^{\mathrm{a}}$ & $6.02 \pm 0.43$ \\
\hline & $\mathrm{T} 3$ & $4.98 \pm 0.45^{\mathrm{Ba}}$ & $6.03 \pm 0.64^{\mathrm{A}}$ \\
\hline \multirow[t]{4}{*}{ Flavor } & $\mathrm{C}$ & $3.78 \pm 0.40^{\mathrm{b}}$ & $3.70 \pm 0.30^{\mathrm{b}}$ \\
\hline & $\mathrm{T} 1$ & $4.35 \pm 0.47^{\mathrm{ab}}$ & $4.93 \pm 0.60^{\mathrm{a}}$ \\
\hline & $\mathrm{T} 2$ & $4.60 \pm 0.38^{\mathrm{a}}$ & $4.83 \pm 0.76^{\mathrm{a}}$ \\
\hline & $\mathrm{T} 3$ & $4.94 \pm 0.76^{\mathrm{a}}$ & $5.52 \pm 0.56^{\mathrm{a}}$ \\
\hline \multirow[t]{4}{*}{ Off-flavor } & $\mathrm{C}$ & $1.40 \pm 0.62^{\mathrm{b}}$ & $1.33 \pm 0.35$ \\
\hline & $\mathrm{T} 1$ & $2.73 \pm 0.53^{\mathrm{Aa}}$ & $1.74 \pm 0.43^{\mathrm{B}}$ \\
\hline & $\mathrm{T} 2$ & $1.33 \pm 0.47^{\mathrm{b}}$ & $1.44 \pm 0.36$ \\
\hline & $\mathrm{T} 3$ & $3.55 \pm 0.53^{\mathrm{Aa}}$ & $2.00 \pm 0.52^{\mathrm{B}}$ \\
\hline \multirow[t]{4}{*}{ Juiciness } & $\mathrm{C}$ & $2.90 \pm 0.20^{\mathrm{Bc}}$ & $3.87 \pm 0.32^{\mathrm{Ac}}$ \\
\hline & $\mathrm{T} 1$ & $5.10 \pm 0.17^{\mathrm{a}}$ & $4.70 \pm 0.62^{\mathrm{ab}}$ \\
\hline & $\mathrm{T} 2$ & $3.73 \pm 0.87^{b}$ & $4.55 \pm 0.42^{\mathrm{bc}}$ \\
\hline & $\mathrm{T} 3$ & $4.95 \pm 0.33^{\mathrm{a}}$ & $5.40 \pm 0.36^{\mathrm{a}}$ \\
\hline \multirow[t]{4}{*}{ Tenderness } & $\mathrm{C}$ & $3.53 \pm 0.59^{\mathrm{Bc}}$ & $4.53 \pm 0.43^{\mathrm{Ac}}$ \\
\hline & $\mathrm{T} 1$ & $5.24 \pm 0.43^{\mathrm{a}}$ & $5.42 \pm 0.44^{\mathrm{b}}$ \\
\hline & $\mathrm{T} 2$ & $5.56 \pm 0.43^{\mathrm{a}}$ & $5.85 \pm 0.81^{\mathrm{ab}}$ \\
\hline & $\mathrm{T} 3$ & $4.14 \pm 0.19^{\mathrm{Bb}}$ & $6.36 \pm 0.36^{\mathrm{Aa}}$ \\
\hline \multirow{4}{*}{$\begin{array}{l}\text { Overall } \\
\text { acceptability }\end{array}$} & $\mathrm{C}$ & $4.60 \pm 0.58$ & $5.08 \pm 0.27^{b}$ \\
\hline & $\mathrm{T} 1$ & $4.86 \pm 0.37^{\mathrm{B}}$ & $5.88 \pm 0.18^{\mathrm{Aa}}$ \\
\hline & $\mathrm{T} 2$ & $5.23 \pm 0.26^{\mathrm{B}}$ & $5.95 \pm 0.45^{\mathrm{Aa}}$ \\
\hline & $\mathrm{T} 3$ & $5.18 \pm 0.39^{B}$ & $6.22 \pm 0.37^{\mathrm{Aa}}$ \\
\hline
\end{tabular}

${ }^{1} \mathrm{C}$, control, salt cured; T1, replacement of salt with soy sauce; T2, replacement of salt with red pepper paste; T3, replacement of salt with soybean paste.

A-B Different capital letter indicate significant differences within curing time $(\mathrm{p}<0.05)$

${ }^{\mathrm{a}-\mathrm{c}}$ Different small letters indicate significant differences within curing solution $(\mathrm{p}<0.05)$.

Based on a 9-point intensity scale $(1=$ dislike extremely or extremely light/bland/tough; and $9=$ like extremely or extremely dark/intense/tender). 
(Albright et al., 2000). All sensory attributes were significant $(\mathrm{p}<0.05)$ in regard to the salt and replacement of the soy sauce, red pepper paste, and soybean paste. The color scores of the beef jerky after replacing salt with soy sauce, red pepper paste and soybean paste were higher than those of the control sample $(p<0.05)$. Further, the color scores of all jerky samples increased at $48 \mathrm{~h}$ of curing time. The flavor scores were significantly higher in all treatments jerky samples than in the control $(\mathrm{p}<0.05)$. The juiciness and tenderness scores were significantly higher in all treatments jerky samples than in the control during $48 \mathrm{~h}$ of curing time $(\mathrm{p}<0.05)$. The overall acceptability scores were improved by replacing salt with soy sauce, red pepper paste, and soybean sauce at $48 \mathrm{~h}$ of curing time $(\mathrm{p}<0.05)$. Also, the overall acceptability scores ranged from 6.22 to 4.60 , with higher acceptability obtained from the beef jerky, in which salt was replaced with soy sauce, red pepper paste, and soybean paste at $48 \mathrm{~h}$ of curing time $(\mathrm{p}<0.05)$.

The soybean is an important food for the supply of essential amino acids, unsaturated fatty acids, isoflavones, phytic acid, saponin, trypsin inhibitors, thchpherol, and oligosaccharides in traditional Korean dietary food (Chung et al., 2011). These substances are the origins of the unique flavors and aromas of the soy beans. Among the various amino acids, it is known that arginine is a good contributor to the salty taste (Breslin and Beauchamp, 1997). The texture of jerky-type snack foods is one of the most important sensory attributes (Lee and Kang, 2003). The jerky's texture can be altered by the moisture content, as is done for other IM meats (Farouk and Swan, 1999). Therefore, it is suggested that replacing salt with soy sauce, red pepper paste, and soybean paste in beef jerky could be used to increase flavor, texture and the overall acceptability of meat products, and provide the consumer with a new food containing these ingredients.

\section{CONCLUSION}

This study has demonstrated that replacing salt with East Asia traditional sauces such as soy sauce, red pepper paste and soybean paste can decrease $\mathrm{Na}^{+}$concentration, lightness and shear force, and enhance the final moisture content and sensory acceptance (color, flavor, tenderness, and overall acceptability) of beef jerky. In particular, the sensory evaluation of beef jerky was enhanced with increasing curing time. Also, replacing salt with red pepper paste and soybean paste resulted in lower lipid oxidation values. The replacement of salt with soy sauce, red pepper paste and soybean paste had a positive effect on quality properties and on reducing the $\mathrm{Na}^{+}$concentration of beef jerky. Therefore, in conclusion the addition of Korean traditional sauces can contribute to the development of reduced-salt meat products with desirable quality characteristics.

\section{ACKNOWLEDGMENTS}

This research was supported by Rural Development Administration (Project No. PJ009848).

The authors thank the Ministry of Education and Human Resources Development for the financial support of the BK21 plus program in Korea. Hyun-Jung Lim and EunYoung Jung were supported by a scholarship from the BK21 plus.

\section{REFERENCES}

Aalhus, J. L. and M. E. R. Dugan. 2004. Oxidative and enzymatic. In: Encyclopedia of meat sciences (Eds. W. K. Jensen, D. Devine, and D. Dikeman). Elsevier, Oxford, UK. pp. 13301336.

Ahn, I. S., M. S. Do, H. S. Jung, Y. I. Kim, H. J. Kim, and K. Y. Park. 2006. Antiobesity effect of Kochujang (Korean fermented red pepper paste) extract in 3T3-L1 adipocytes. J. Med. Food 9:15-21.

Albright, S. N., P. A. Kendall, and J. N. Sofos. 2000. Sensory properties of beef jerky processed under various conditions. In: Proceedings of IFT annual meeting. Dallas, TX, USA, Session 11.

Anderson, J. W., B. M. Johnstone, and M. E. Cook-Newll. 1995. Meta-analysis of the effects of soy protein intake on serum lipids. N. Engl. J. Med. 333:276-282.

Andres, A. I., R. Cava, D. Martin, J. Ventanas, and J. Ruiz. 2005. Lipolysis in dry-cured ham: Influence of salt content and processing conditions. Food Chem. 90:523-533.

AOAC. 2000. Official Methods of Analysis. 17th ed. Association of Official Analytical Chemists. Gaithersburg, MD, USA.

Breslin, P. A. and G. K. Beauchamp. 1997. Salt enhances flavour by suppressing bitterness. Nature 387:563.

Brewer, S., J. Jenson, A. A. Sosnicki, B. Field, E. Wilson, and F. McKeith. 2002. The effect of pig genetics palatability, color and physical characteristics of fresh loin chops. Meat Sci. 61:249-256.

Chang, S. F., T. C. Huang, and A. M. Pearson. 1991. Some parameters involved in production of Zousoon-A semi-dry, long fibered pork product. Meat Sci. 30:303-325.

Chen, W. S., D. C. Lin, and M. T. Chen. 2002. Effects of high level of sucrose on the moisture content, water activity, protein denaturation, and sensory properties in Chinese-style pork jerky. Asian Australas. J. Anim. Sci. 15:585-590.

Choo, J. J. 2000. Antiobesity effects of Kochujang in rats fed on a high-fat diet. Korean J. Nutr. 33:787-793.

Chung, I. M., S. H. Seo, J. K. Ahn, and S. H. Kim. 2011. Effect of processing, fermentation, and aging treatment to contain and profile of phenolic compounds in soybean seed, soy curd and soy paste. Food Chem. 127:906-967.

Chinachoti, P. and S. J. Schmidt. 1991. Solute-polymer water interactions and their manifestations. In: Water relationships in foods: Advances in the 1980s and trends for the 1990s (Eds. H. Levine and L. Slade). Premium Press, New York. Adv. Exp. Med. Biol. 302:561-584. 
Costa-Corredor, A., X. Serra, J. Arnau, and P. Gou. 2009. Reduction of $\mathrm{NaCl}$ content in restructured dry-cured hams: Post-resting temperature and drying level effects on physicochemical and sensory parameters. Meat Sci. 83:390397.

Farouk, M. M. and J. E. Swan. 1999. Boning and storage temperature effects on the attributes of soft jerky and frozen cooked free-flow mince. J. Food Sci. 64:465-468.

Flores, M., M. C. Aristoy, A. M. Spanier, and F. Toldra. 1997. Non-volatile components effects on quality of "Serrano" drycured ham as related to processing time. J. Food Sci. 62:12351239.

Gailani, D. M., D. Y. C. Fung, and A. A. Kraft. 1986. Critical review of water activities and microbiology of drying of meats. CRC Crit. Rev. Food Sci. Nutr. 25:159-183.

Guerreo, L., P. Gou, and J. Arnau. 1999. The influence of meat pH on mechanical and sensory textural properties of dry-cured ham. Meat Sci. 52:267-273.

Han, D. J., E. S. Lee, S. K. Lee, and C. J. Kim. 2011. Effects of hot boning and soy sauce on the processing properties of semidried beef jerky. Korean J. Food Sci. Anim. Resour. 31:497505.

Hee, F. J. and G. A. MacGregor. 2010. Reducing population salt intake worldwide: From evidence to implementation. Prog. Cardiovasc. Dis. 52:363-382.

Jose, F. S., G. Rafael, and A. C. Miguel. 1994. Water activity of Spanish intermediate moisture meat products. Meat Sci. 38:341-350.

Kim, J. Y., K. W. Park, H. S. Yang, Y. S. Cho, C. H. Jeong, K. H. Shim, S. T. Lee, and K. I. Seo. 2005. Anticancer and immunoactivity of methanol extract from onion Kochujang. Korean J. Food Preserv. 12:173-178.

Labuza, T. P., S. R. Tannenbaum, and M. Karel. 1970. Water content and stability of low-moisture and intermediatemoisture foods. Food Technol. 24:543-550.

Larrea, V., I. Perez-Munuera, I. Hernando, A. Quiles, and M. A. Lluch. 2007. Chemical and structural changes in lipids during the ripening of Teruel dry-cured ham. Food Chem. 102:494503.

Lee, S. W. and C. S. Kang. 2003. Effects of moisture content and drying temperature on the physicochemical properties of ostrich jerky. Food/Nahrung 47:330-333.
Leistner, L. 1987. Shelf-stable products and intermediate moisture foods based on meat. In: Water Activity: Theory and Applications to Foods (Eds. L. B. Rockland and L. R. Beuchat). Marcel Dekker, New York, USA. pp. 295-328.

Lim, H. J., E. Y. Jung, G. D. Kim, S. T. Joo, and H. S. Yang. 2013. Quality properties of beef jerky replaced salt with soy sauce, red pepper paste and soybean paste during storage. Korean J. Food Sci. Anim. Resour. 33:181-188.

Obanu, Z. A. 1988. Preservation of meat in Africa by control of the internal aqueous environment in relation to product quality and stability. In: Food Preservation by Moisture Control (Eds. C. C. Seow, T. T. Teng, and C. H. Queh). 2nd ed. Elsevier Applied Science, London, UK. p.161-173.

McCarty, M. F. 2004. Should we restrict chloride rather than sodium? Med. Hypotheses 63:138-148.

Meilgaard, M., G. V. Civille, and B. T. Carr. 1999. Sensory evaluation techniques. 3rd ed. Boca Ration, CRC Press FL, USA. p. 354.

Quinton, R. D., D. P. Cornforth, D. G. Hendricks, C. P. Brennand, and Y. K. Su. 1997. Acceptability and composition of some acidified meat and vegetable stick products. J. Food Sci. 62:1250-1254.

Sárraga, C. and J. A. Garćia-Regueiro. 1998. Oxidation of microsomal fraction in the processing conditions of dry-cured ham. The in-vitro effect of brine. Meat Sci. 50:295-302.

SAS Institute. 2000. SAS/STAT Software for PC. Release 9.2, Cary, NC, USA.

Sinnhuber, R. O. and T. C. Yu. 1977. The 2-thiobarbituric acid reaction, an objective measure of the oxidative determination occurring in fats and oils. J. Am. Oil Chemist's Soc. 26:259267.

Yang, H. S., Y. H. Hwang, S. T. Joo, and G. B. Park. 2009a. The physicochemical and microbiological characteristics of pork jerky in comparison to beef jerky. Meat Sci. 82:289-294.

Yang, H. S., S. W. Kang, J. Y. Jeong, J. Y. Chun, S. T. Joo, G. B. Park, and S. G. Choi. 2009b. Optimization of drying temperature and time for pork jerky using response surface methodology. Food Sci. Biotechnol. 18:985-990.

Zhang, Y. C., D. Albrecht, J. Bomser, S. J. Schwartz, and Y. Vodovotz. 2003. Isoflavone profile and biological activity of soy bread. J. Agric. Food Chem. 51:7611-7616. 